UDC 537.6; 538.9; 548.3

\title{
CRYSTAL STRUCTURE AND MAGNETIC PROPERTIES $\mathrm{OF}\left(\mathrm{Cr}_{0.34} \mathrm{Cu}{ }_{0.10 N i} \mathrm{Ni}_{56}\right)_{4} \mathrm{Si}$
}

\author{
R.-I. Martyniak ${ }^{1 *}$, N. Muts ${ }^{1}$, A. Horyn ${ }^{1}$, Ya. Tokaychuk ${ }^{1}$, M. Bobnar ${ }^{2}$, \\ L. Akselrud ${ }^{1,3}$, R. Gladyshevskii ${ }^{1}$ \\ ${ }^{1}$ Department of Inorganic Chemistry, Ivan Franko National University of Lviv, \\ Kyryla i Mefodiya Str., 6, 79005 Lviv, Ukraine; \\ ${ }^{2}$ Department of Condensed Matter Physics, Jožef Stefan Institute, \\ Jamova Cesta, 39, 1000 Ljubljana, Slovenia; \\ ${ }^{3}$ Max Planck Institut für Chemische Physik fester Stoffe, \\ Nöthnitzer Straße, 40, 01187 Dresden, Germany \\ e-mail: martyniak241@gmail.com
}

\begin{abstract}
The crystal structure of the $\pi$ phase $(\mathrm{Cr}, \mathrm{Cu}, \mathrm{Ni}) 4 \mathrm{Si}$ was refined from $\mathrm{X}$-ray powder diffraction data and found to belong to the $\mathrm{BMn}$ structure family, namely, to the structure type $\mathrm{Au} 4 \mathrm{Al}$ (Pearson symbol $c P 20$, space group $P 2{ }_{1} 3$ ): unit-cell parameter $a=0.612269(8) \mathrm{nm}$ for $\left(\mathrm{Cr}_{0.34(1)} \mathrm{Cu}_{0.10(1)} \mathrm{Ni}_{0.56(1)}\right)_{4} \mathrm{Si}$ (composition from EDS). The temperature dependence of the magnetic susceptibility of a sample of nominal composition $\mathrm{Cr}_{26} \mathrm{Cu}_{9} \mathrm{Ni}_{47} \mathrm{Si}_{18}$, containing more than 96 wt.\% of the title compound, revealed

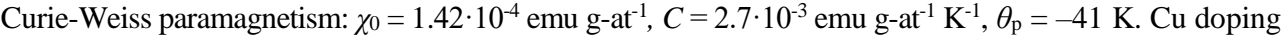
decreased the paramagnetic temperature to more negative values.
\end{abstract} skyrmions.

Keywords: X-ray powder diffraction, crystal structure, magnetic properties, magnetic

DOI: https://doi.org/10.30970/vch.6101.093

\section{Introduction}

Globalization trends in the modern world create a need for efficient and reliable data storage technology. Current data storage devices have significant flaws, e.g. they have too low information storage density and are sensitive to external conditions. These problems can, however, be addressed by using novel quantum materials. Skyrmionic materials, ferromagnets containing whirling nanoscopic spin texture defects called magnetic skyrmions, may one day supersede the classical ferromagnetic materials used in RAM (Random Access Memory) and DWM (Domain Wall Memory) technologies [1]. Their superiority over the usual ferromagnets lies in the small size of a magnetic skyrmion (sometimes less than $10 \mathrm{~nm}$ ) and the simplicity of skyrmion manipulation in a conductor. These two factors justify the interest in industrial synthesis of skyrmionic materials.

The aforementioned merits of skyrmionic materials have directed our research into this area. The existence of magnetic skyrmions in a conductor is restricted by two conditions: one structural and the other one magnetic. On the one hand, magnetic skyrmions

(C) Martyniak R.-I., Muts N., Horyn A. et al., 2020 
R.-I. Martyniak, N. Muts, A. Horyn et al.

can only be nucleated in solids crystallizing in one of the 22 enantiomorphic space groups. On the other hand, a skyrmionic spin state is only observed for materials having a slightly positive paramagnetic Curie temperature. This work is a continuation of previous investigations [2-5] on the $\pi$ phase in the $\mathrm{Cr}-\mathrm{Ni}-\mathrm{Si}$ system [6] and the effect of element substitution on the crystal structure and magnetic properties, and presents the results of investigations of $\mathrm{C}_{26} \mathrm{Cu}_{9} \mathrm{Ni}_{47} \mathrm{Si}_{18}$ alloy.

\section{Materials and experimental procedures}

A sample of nominal composition $\mathrm{Cr}_{26} \mathrm{Cu}_{9} \mathrm{Ni}_{47} \mathrm{Si}_{18}$ was prepared by arc-melting of pure $(\geq 99.9$ wt. \%) elements under a purified argon atmosphere. The mass of the alloy was $1 \mathrm{~g}$ and the loss during the preparation was less than $1 \%$ of the total mass. The alloy was annealed at $1173 \mathrm{~K}$ for 35 days in an evacuated quartz ampoule, and quenched in cold water thereafter. The crystal structure was refined from X-ray powder diffraction data recorded with a Huber Image Plate Camera G670 diffractometer $\left(\mathrm{Cu} K \alpha_{1}\right.$ radiation), using the FullProf Suite package [7]. The temperature dependence of the magnetic susceptibility was measured on a SQUID magnetometer (MPMS-XL7, Quantum Design) in external fields of 3.5 and $7.0 \mathrm{~T}$ in the temperature range $1.8-300 \mathrm{~K}$. A high-temperature differential scanning calorimetry (DSC) curve of the $\mathrm{Cr}_{26} \mathrm{Cu}_{9} \mathrm{Ni}_{47} \mathrm{Si}_{18}$ alloy was obtained using a Linseis simultaneous thermo analytical instrument STA PT 1600 in a dynamic atmosphere of $\operatorname{argon}\left(\sim 6 \mathrm{dm}^{3} / \mathrm{h}\right)$ with heating/cooling rates of $10 \mathrm{~K} / \mathrm{min}$ in the temperature range between 293 and $1423 \mathrm{~K}$.

The elemental composition of the sample was determined using energy-dispersive $\mathrm{X}$-ray spectroscopy (EDS) using an $\mathrm{X}-\mathrm{Max}^{\mathrm{N}}$ microanalysis system and a scanning electron microscope (SEM) Tescan Vega 3. The compositions of the individual phases present in the sample were determined by EDS analysis using AZtecLive real-time chemical imaging powered by an X-Max ${ }^{\mathrm{N}}$ Silicon Drift Detector.

\section{Results and discussion}

The result of the EDS analysis of the $\mathrm{Cr}_{26} \mathrm{Cu}_{9} \mathrm{Ni}_{47} \mathrm{Si}_{18}$ sample showed good agreement with the nominal composition (Table 1). The sample was found to contain two phases: a main phase (gray region) with the composition $\mathrm{Cr}_{28.1(6)} \mathrm{Cu}_{4.7(6)} \mathrm{Ni}_{48(1)} \mathrm{Si}_{19.2(6)}$ and a secondary phase (pale gray regions) with the composition $\mathrm{Cu}_{76(5)} \mathrm{Ni}_{17(3)} \mathrm{Cr}_{6(2)} \mathrm{Si}_{1.0(5)}$ (Fig. 1).

A complete structure refinement using the Rietveld method was performed on X-ray powder diffraction data obtained for the $\mathrm{Cr}_{26} \mathrm{Cu}_{9} \mathrm{Ni}_{47} \mathrm{Si}_{18}$ sample (Fig. 2). The phase analysis showed that the alloy contained, as expected, as main component the $(\mathrm{Cr}, \mathrm{Cu}, \mathrm{Ni})_{4} \mathrm{Si}$ phase crystallizing in the enantiomorphic space group $P 2_{1} 3$ (structure type $\mathrm{Au}_{4} \mathrm{Al}$, which is an ordered derivative of the $\beta \mathrm{Mn}$ type, Pearson symbol $c P 20$ [8]). However, the sample was also found to contain approximately $4 \mathrm{wt} . \%$ of an additional phase based on elementary $\mathrm{Cu}$ dissolving mainly $\mathrm{Ni}$ (structure type $\mathrm{Cu}$, Pearson symbol $c F 4$, space group $F m-3 m$ [8]). The positional coordinates and isotropic displacement parameters of the atoms in the structure of $\left(\mathrm{Cr}_{0.34(1)} \mathrm{Cu}_{0.10(1)} \mathrm{Ni}_{0.56(1)}\right)_{4} \mathrm{Si}$ are given in Table 2; details of the structural refinement are summarized in Table 3. The cell parameter of the title compound, 0.612269(8) nm, is very close to the value reported for the $\pi$ phase in the $\mathrm{Cr}-\mathrm{Ni}-\mathrm{Si}$ system $(0.6120 \mathrm{~nm}$ [8]). Due to the similar number of electrons of the constituting metal atoms, the statistical mixture of $\mathrm{Cr}$, $\mathrm{Ni}$, and $\mathrm{Cu}$ atoms at the Wyckoff positions $12 b$ and $4 a$ in the $(\mathrm{Cr}, \mathrm{Cu}, \mathrm{Ni})_{4} \mathrm{Si}$ phase was fixed at $M 1=M 2=\mathrm{Cr}_{0.34} \mathrm{Cu}_{0.10} \mathrm{Ni}_{0.56}$, i.e. the proportions determined by the EDS analysis. The cell parameter of the $(\mathrm{Cu}, \mathrm{Ni})$ solid solution containing small amounts of $\mathrm{Cr}$ and $\mathrm{Si}$, $0.360171(7) \mathrm{nm}$, is also in good agreement with values for $(\mathrm{Cu}, \mathrm{Ni})$ reported in the literature [8]. 
R.-I. Martyniak, N. Muts, A. Horyn et al.

ISSN 2078-5615. Visnyk of the Lviv University. Series Chemistry. 2020. Issue 61. Pt. 1

Results (at.\%) of the EDS investigation of the $\mathrm{Cr}_{26} \mathrm{Cu}_{9} \mathrm{Ni}_{47} \mathrm{Si}_{18}$ sample

Table 1

\begin{tabular}{|c|c|c|c|}
\hline Element & Overall composition & Main phase & Secondary phase \\
\hline $\mathrm{Cr}$ & 27.4 & $28.1(6)$ & $6(2)$ \\
$\mathrm{Cu}$ & 8.4 & $4.7(6)$ & $76(5)$ \\
$\mathrm{Ni}$ & 45.8 & $48(1)$ & $17(3)$ \\
$\mathrm{Si}$ & 18.4 & $19.2(6)$ & $1.0(5)$ \\
\hline
\end{tabular}

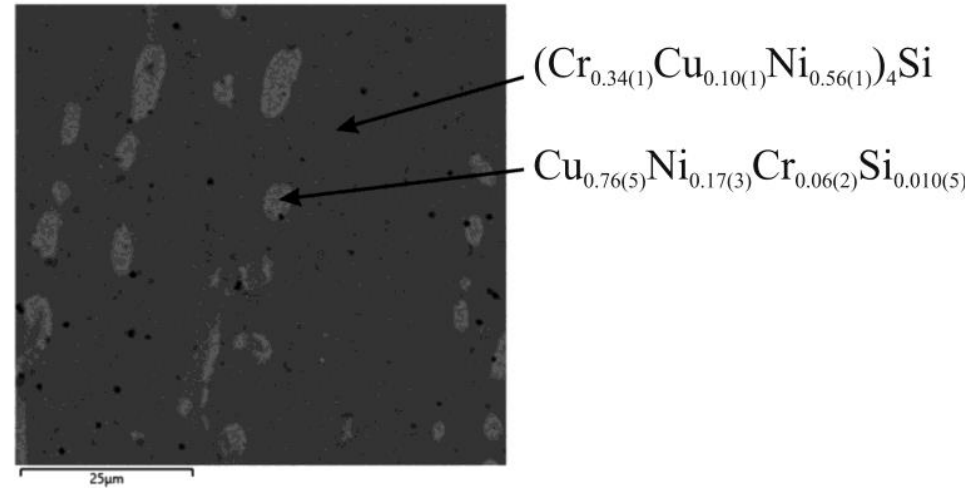

Fig. 1. SEM photograph of the $\mathrm{Cr}_{26} \mathrm{Cu}_{9} \mathrm{Ni}_{47} \mathrm{Si}_{18}$ sample:

gray matrix $-\left(\mathrm{Cr}_{0.34(1)} \mathrm{Cu}_{0.10(1)} \mathrm{Ni}_{0.56(1)}\right)_{4} \mathrm{Si}$; light gray regions $-\mathrm{Cu}_{0.76(5)} \mathrm{Ni}_{0.17(3)} \mathrm{Cr}_{0.06(2)} \mathrm{Si}_{0.010(5)}$

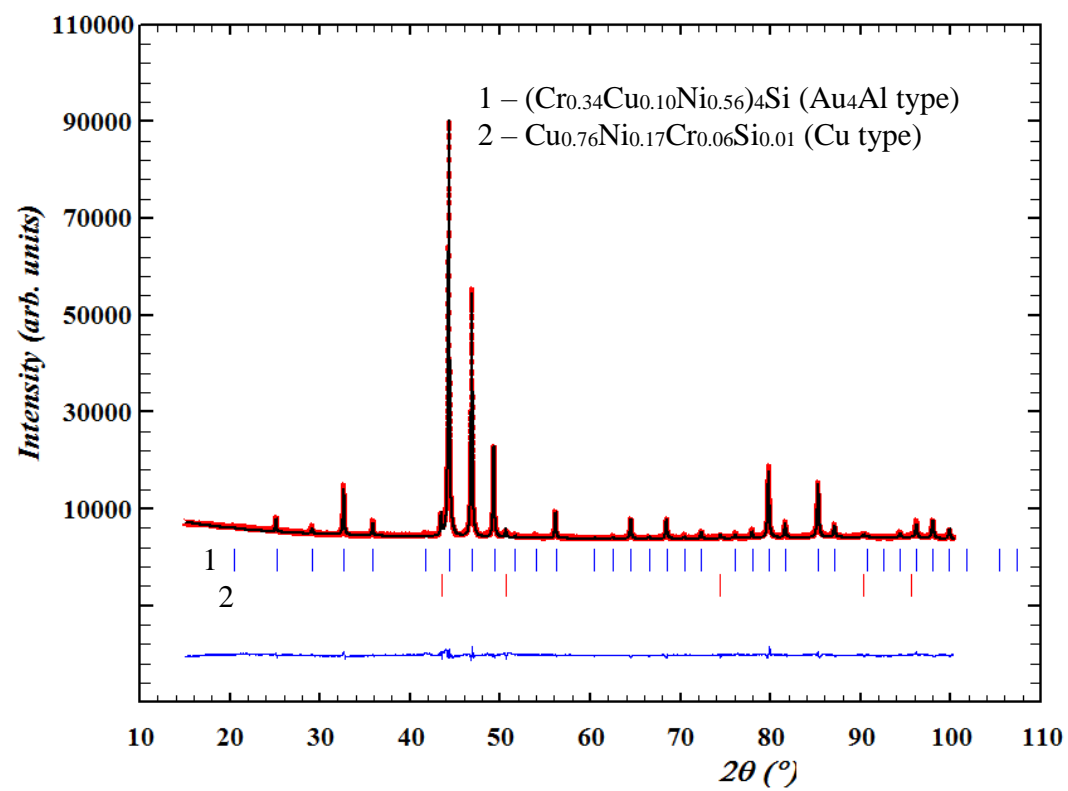

Fig. 2. Observed, calculated and difference (bottom) X-ray powder diffraction patterns for the $\mathrm{Cr}_{26} \mathrm{Cu}_{9} \mathrm{Ni}_{47} \mathrm{Si}_{18}$ sample annealed at $1173 \mathrm{~K}$ for 35 days; $\mathrm{Cu} K \alpha_{1}$ radiation $(\lambda=0.154060 \mathrm{~nm})$ 
R.-I. Martyniak, N. Muts, A. Horyn et al. ISSN 2078-5615. Visnyk of the Lviv University. Series Chemistry. 2020. Issue 61. Pt. 1

Table 2

Atomic coordinates and isotropic displacement parameters for $\left(\mathrm{Cr}_{0.34} \mathrm{Cu}_{0.10} \mathrm{Ni}_{0.56}\right)_{4} \mathrm{~S}$ (structure type $\mathrm{Au}_{4} \mathrm{Al}$, Pearson symbol $c P 20$, space group $P 2{ }_{1} 3$ )

\begin{tabular}{|c|c|l|l|c|c|}
\hline \multirow{2}{*}{ Site } & \multirow{2}{*}{$\begin{array}{c}\text { Wyckoff } \\
\text { position }\end{array}$} & \multicolumn{3}{|c|}{ Atomic coordinates } & \multicolumn{1}{|c|}{$B_{\text {iso }}$} \\
\cline { 3 - 5 } & \multicolumn{1}{|c|}{$x$} & \multicolumn{1}{|c|}{$y$} & \multicolumn{1}{c|}{$z$} & $\left(10^{2} \mathrm{~nm}^{2}\right)$ \\
\hline$M 1$ & $12 b$ & $0.79689(15)$ & $0.95313(13)$ & $0.37842(19)$ & $1.42(2)$ \\
$M 2$ & $4 a$ & $0.68571(16)$ & $0.68571(16)$ & $0.68571(16)$ & $1.36(5)$ \\
$\mathrm{Si}$ & $4 a$ & $0.0695(3)$ & $0.0695(3)$ & $0.0695(3)$ & $0.49(7)$ \\
\hline
\end{tabular}

$M 1=M 2=\mathrm{Cr}_{0.34} \mathrm{Cu}_{0.10} \mathrm{Ni}_{0.56}$.

Table 3

Experimental details and crystallographic data for the individual phases in the $\mathrm{Cr}_{26} \mathrm{Cu}_{9} \mathrm{Ni}_{47} \mathrm{Si}_{18}$ alloy

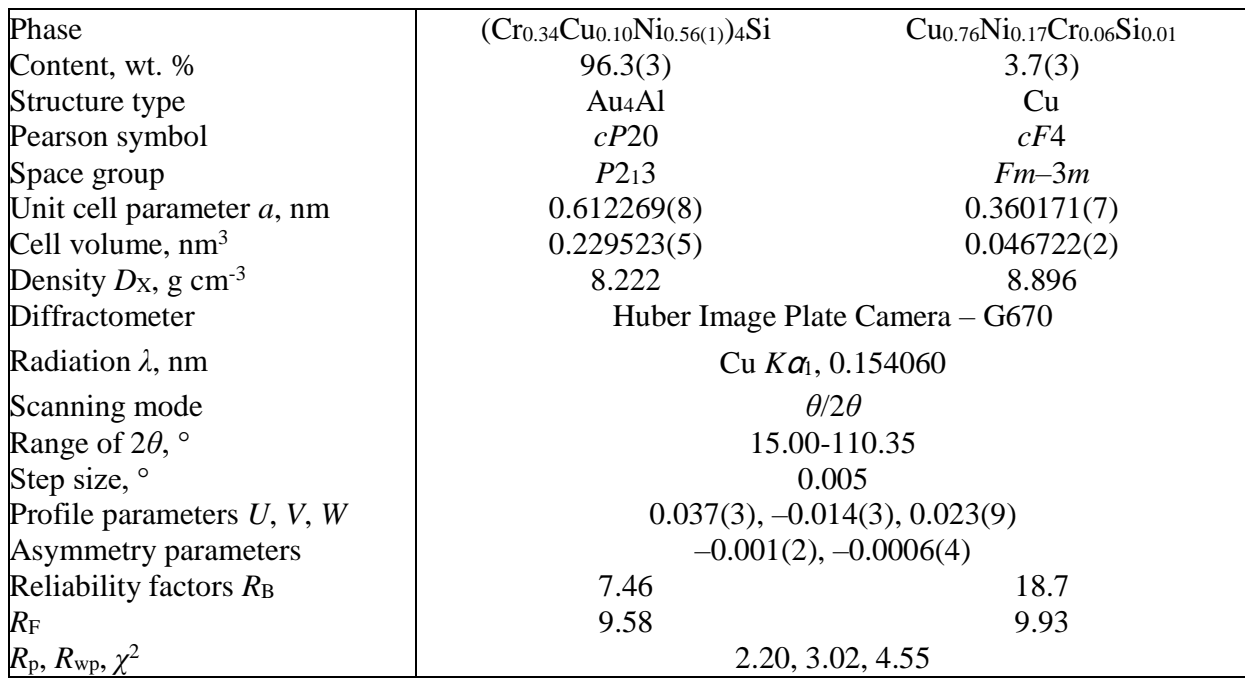

The $\mathrm{Cr}_{26} \mathrm{Cu}_{9} \mathrm{Ni}_{47} \mathrm{Si}_{18}$ sample was also investigated by high-temperature differential scanning calorimetry. In an earlier investigation of the $\mathrm{Cr}-\mathrm{Ni}-\mathrm{Si}$ system [9] the $\pi$ phase was observed at $1123 \mathrm{~K}$, but not at $1073 \mathrm{~K}$, which seemed to indicate a eutectoid decomposition taking place between these two temperatures. The DSC curve of the $\mathrm{Cr}_{26} \mathrm{Cu}_{9} \mathrm{Ni}_{47} \mathrm{Si}_{18}$ sample (Fig. 3) exhibits two peaks. The first, narrow peak appears at 1293-1297 K, and the second, broader, asymmetric peak at 1347-1373 K. Such a diagram may describe incongruent melting of the main phase, where the former peak corresponds to the solidus (melting temperature) and the latter to the liquidus. Five different ternary phases were observed in the isothermal section of the phase diagram of the $\mathrm{Cr}-\mathrm{Ni}-\mathrm{Si}$ system at $1123 \mathrm{~K}$ [9], some of them in a relatively narrow composition region, increasing the probability of incongruent melting. Melting of the additional phase identified as a solid solution based on $(\mathrm{Cu}, \mathrm{Ni})$ with low amounts of $\mathrm{Cr}$ and $\mathrm{Si}$ (composition from EDS analysis $\mathrm{Cr}_{6(2)} \mathrm{Cu}_{76(5)} \mathrm{Ni}_{17(3)} \mathrm{Si}_{1.0(5)}$ ) is expected to occur close to the experimental limit of the investigation (1423 K). Elementary $\mathrm{Cu}$ forms a continuous solid solution with $\mathrm{Ni}$, where the melting point steadily increases from $1358 \mathrm{~K}$ for $\mathrm{Cu}$ to $1728 \mathrm{~K}$ for $\mathrm{Ni}[10]$ and 17 at. \% Ni corresponds to approximately $1423 \mathrm{~K}$. Pure $\mathrm{Cu}$ dissolves less than 1 at. \% $\mathrm{Cr}$, but $\mathrm{Ni}$ dissolves up to 50 at. \% $\mathrm{Cr}$, which reduces the melting point to $1618 \mathrm{~K}$. From our investigations, including earlier DSC of a $\mathrm{Cr}_{30} \mathrm{Ni}_{50} \mathrm{Si}_{20}$ sample [2], we see no indication of a eutectoid decomposition or other transition of the $\pi$ phase in the temperature range between 1073 and $1123 \mathrm{~K}$. 
R.-I. Martyniak, N. Muts, A. Horyn et al.

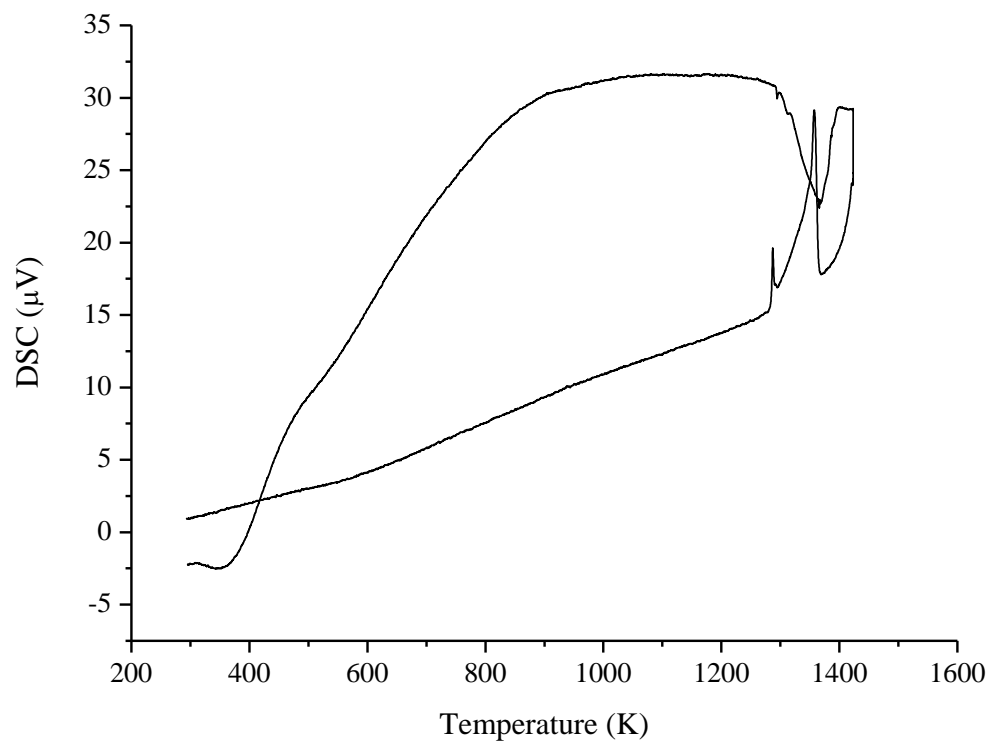

Fig. 3. DSC curve for the $\mathrm{Cr}_{26} \mathrm{Cu}_{9} \mathrm{Ni}_{47} \mathrm{Si}_{18}$ sample

The parent $(\mathrm{Cr}, \mathrm{Ni})_{4} \mathrm{Si}$ phase shows Curie-Weiss paramagnetic behavior with a paramagnetic Curie temperature from $-13 \mathrm{~K}$ to $-15 \mathrm{~K}$ [3]. Magnetic measurements of the $\mathrm{Cr}_{26} \mathrm{Cu}_{9} \mathrm{Ni}_{47} \mathrm{Si}_{18}$ sample were performed in two magnetic fields $(3.5$ and $7.0 \mathrm{~T})$. The temperature dependence of the magnetic susceptibility in the range 1.8-300 K, shown in Fig. 4, revealed paramagnetic behavior above $20 \mathrm{~K}$ also for the $\mathrm{Cu}$-doped sample.

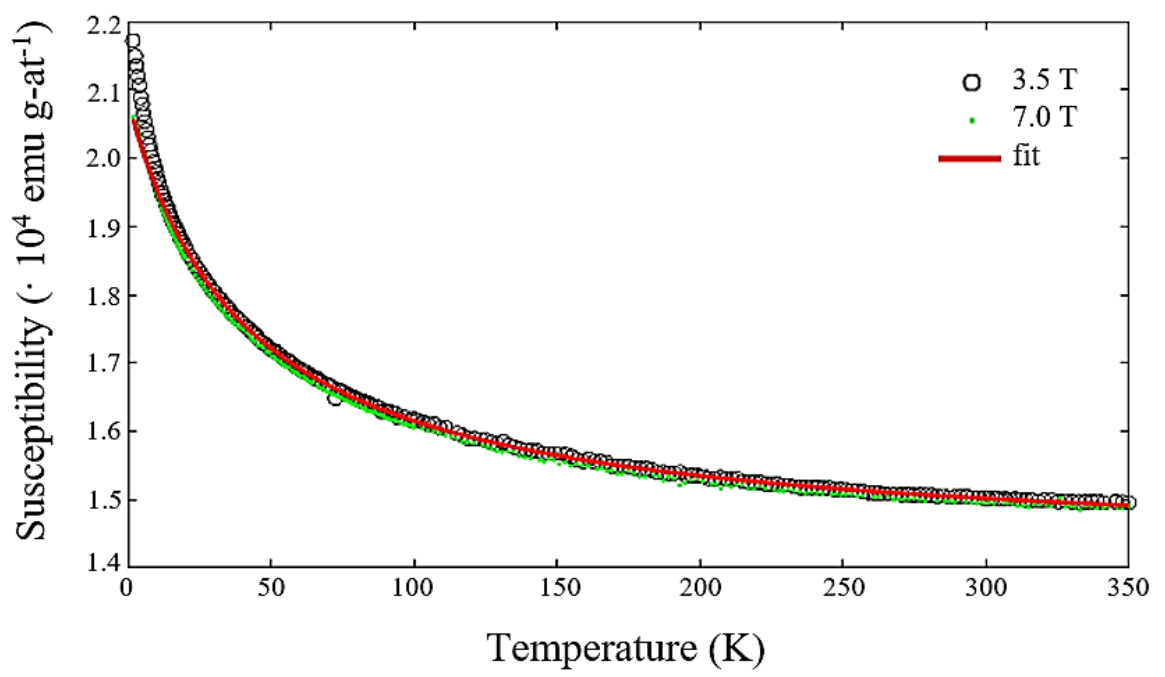

Fig. 4. Temperature dependence of the magnetic susceptibility of the $\mathrm{Cr}_{26} \mathrm{Cu}_{9} \mathrm{Ni}_{47} \mathrm{Si}_{18}$ alloy, measured in magnetic fields of 3.5 and 7.0 T. The red solid line shows the modified Curie-Weiss fit at $3.5 \mathrm{~T}$ 
R.-I. Martyniak, N. Muts, A. Horyn et al.

The use of two different fields showed that the susceptibility is slightly fielddependent, which can be attributed to a tiny ferromagnetic impurity, equivalent to $5 \mathrm{ppm}$ of metallic iron. It is known that elementary $\mathrm{Ni}$ is a ferromagnet, and the solid solution $(\mathrm{Cu}$, $\mathrm{Ni}$ ) remains ferromagnetic with $T_{\mathrm{C}}$ decreasing with increasing $\mathrm{Cu}$ content. The data obtained at $3.5 \mathrm{~T}$ were fit to a modified Curie-Weiss law $\chi=\chi_{0}+C /\left(T-\theta_{\mathrm{p}}\right)$, where $C=2.7 \cdot 10^{-3}$ emu g-at ${ }^{-1} \mathrm{~K}^{-1}$ is the Curie constant, $\theta_{\mathrm{p}}=-41 \mathrm{~K}$ is the paramagnetic Curie temperature, and $\chi_{0}=1.42 \cdot 10^{-4} \mathrm{emu} \mathrm{g}$-at $^{-1}$ is the temperature-independent contribution to the susceptibility. The negative Curie temperature indicates antiferromagnetic interactions and the effective magnetic moment $\mu_{\text {eff }}$ calculated from the Curie constant is $0.147 \mu_{\mathrm{B} / \text { atom. }}$ $\chi_{0}$ is the sum of a positive Pauli paramagnetic contribution of the conduction electrons $\chi_{\text {Pauli }}$ and a negative diamagnetic contribution of the core electrons $\chi_{\mathrm{dia}}=-7.59 \cdot 10^{-6} \mathrm{emu} \mathrm{g}^{-\mathrm{at}^{-1}}$, which was calculated for $\mathrm{Cr}^{6+}, \mathrm{Cu}^{2+}, \mathrm{Ni}^{2+}$, and $\mathrm{Si}^{4+}$ ions [11]. Thus, the contribution of the conduction electrons equals $\chi_{\text {Pauli }}=\chi_{0}-\chi_{\text {dia }}=1.49 \cdot 10^{-4} \mathrm{emu} \mathrm{g}$-at $^{-1}$, which corresponds to a density of states at the Fermi level $g\left(E_{\mathrm{F}}\right)=4.61$ states/(eV atom). This is higher than the density of states at the Fermi level of metallic Ni (4.06 states/(eV atom)) and indicates electron correlations and an enhancement of the susceptibility. A phase with $\mathrm{Au}_{4} \mathrm{Al}$-type structure is also known in the $\mathrm{Fe}-\mathrm{Ni}-\mathrm{Si}$ system [12] with a relatively broad homogeneity range extending along the isoconcentrate 20 at. \% Si. This phase exhibits ferromagnetic order with a Curie temperature of 550-650 K, depending on the Fe content, for the same structure type. Our previous attempts to partially replace $\mathrm{Cr}$ and/or $\mathrm{Ni}$ by $\mathrm{Fe}, \mathrm{Ru}, \mathrm{Co}$, or $\mathrm{Pd}$ in the $(\mathrm{Cr}, \mathrm{Ni})_{4} \mathrm{Si}$ phase, revealed the following paramagnetic Curie temperatures for samples of nominal composition $\mathrm{Cr}_{28} M_{5} \mathrm{Ni}_{49} \mathrm{Si}_{18}$ : $-7 \mathrm{~K}$ for $M=\mathrm{Fe}$ [4], $\mathrm{Cr}_{27} M_{5} \mathrm{Ni}_{48} \mathrm{Si}_{20}$ : $-52 \mathrm{~K}$ for $M=\mathrm{Co}$ [3], i.e. in all these cases the interactions remained antiferromagnetic.

\section{Conclusions}

The crystal structure of the $\mathrm{Cu}$-doped $\pi$ phase $(\mathrm{Cr}, \mathrm{Ni})_{4} \mathrm{Si}$ was refined from $\mathrm{X}$-ray powder diffraction data of a $\mathrm{Cr}_{26} \mathrm{Cu}_{9} \mathrm{Ni}_{47} \mathrm{Si}_{18}$ sample annealed at $1173 \mathrm{~K}$. Most of the $\mathrm{Cu}$ had been incorporated, but the alloy contained two phases: the quantitatively predominant (96.3(3) wt. \%) $\left(\mathrm{Cr}_{0.34(1)} \mathrm{Cu}_{0.10(1)} \mathrm{Ni}_{0.56(1)}\right)_{4} \mathrm{Si}$ phase and a $(\mathrm{Cu}, \mathrm{Ni})$-based solid solution of composition $\mathrm{Cu}_{0.76(5)} \mathrm{Ni}_{0.17(3)} \mathrm{Cr}_{0.06(2)} \mathrm{Si}_{0.010(5)}(3.7$ wt. \%). Measurements of the temperature dependence of the magnetic susceptibility showed paramagnetic behavior. As previously observed for doping by $\mathrm{Co}\left(\theta_{\mathrm{p}}=-52 \mathrm{~K}\right)$ [3], substitution of $\mathrm{Cu}$ atoms for $\mathrm{Cr}$ and $\mathrm{Ni}$ led to a significant decrease of the value of the paramagnetic Curie temperature $\left(\theta_{\mathrm{p}}=-41 \mathrm{~K}\right)$, compared to values between -13 and $-15 \mathrm{~K}$ for the parent phase. Previous substitution by $\mathrm{Fe}, \mathrm{Ru}$, or $\mathrm{Pd}$ reduced the absolute value of $\theta_{\mathrm{p}}$, but the interactions remained antiferromagnetic $[4,5]$.

The enantiomorphic crystal structure of the title compound was confirmed, however, magnetic properties propitious for the formation of skyrmions, i.e. a slightly positive paramagnetic Curie temperature, were not obtained by replacing $\mathrm{Cr}$ and/or $\mathrm{Ni}$ by $\mathrm{Cu}$.

\section{Acknowledgements}

We thank Dr Karin Cenzual from Geneva University for useful discussions. 
1. Fert A., Reyren N., Cros V. Magnetic Skyrmions: Advances in Physics and Potential Applications // Nat. Rev. Mater. 2017. Vol. 2. P. 17031.

DOI: http://dx.doi.org/10.1038/natrevmats.2017.31

2. Martyniak R.-I., Muts N., Akselrud L., Gladyshevskii R. Synthesis and Structural Investigation of Samples in the Cr-Ni-Si System // Visn. Lviv Univ. Ser. Khim. 2018. Vol. 59. P. 76-82 (in Ukrainian). DOI: http://dx.doi.org/10.30970/vch.5901.076

3. Martyniak R.-I., Muts N., Sichevych O., Borrmann H., Bobnar M., Akselrud L., Gladyshevskii R. Structure and Magnetic Properties of $(\mathrm{Cr}, \mathrm{Ni})_{4-x} \mathrm{Co}_{x} \mathrm{Si} / /$ Solid State Phenom. 2019. Vol. 289. P. 108-113.

DOI: http://dx.doi.org/10.4028/www.scientific.net/SSP.289.108

4. Martyniak R.-I., Muts N., Bobnar M., Akselrud L., Gladyshevskii R. Structure and Magnetic Properties of $(\mathrm{Cr}, T, \mathrm{Ni})_{4} \mathrm{Si}$ Phases $(T=\mathrm{Cu}, \mathrm{Fe}, \mathrm{Pd}) / /$ Book Abstr. Int. Conf. Stud. Young Scient. Theor. Exper. Phys. "HEUREKA-2019”. 2019. Lviv. P. A14.

5. Martyniak R.-I., Muts N., Bobnar M., Akselrud L., Gladyshevskii R. Crystal Structure and Magnetic Properties of $\mathrm{Cr}-\{\mathrm{Ru}, \mathrm{Pd}\}-\mathrm{Ni}-\mathrm{Si}$ Phases // Coll. Abstr. XIV Int. Conf. Cryst. Chem. Intermet. Compd. 2019. Lviv. P. 150.

6. Gladyshevskii E. I., Kripyakevich P. I., Kuz'ma Yu. B. The Crystal Structure of LowSilicon Ternary Compounds in the $\mathrm{Cr}-\mathrm{Ni}-\mathrm{Si}$ and $\mathrm{Cr}-\mathrm{Co}-\mathrm{Si}$ Systems // J. Struct. Chem. 1962. Vol. 3. P. 402-410.

7. Rodriguez-Carvajal J. Recent Developments of the Program FullProf // Newsletter in Commission on Powder Diffraction (IUCr). 2001. Vol. 26. P. 12-19.

8. Villars P., Cenzual K. (Eds.) Pearson's Crystal Data - Crystal Structure Database for Inorganic Compounds, ASM International: Materials Park, OH, USA, Release 2017/18.

9. Gladyshevskii E. I., Borusevich L. K. The Cr-Ni-Si Ternary System // Russ. J. Inorg. Chem. 1963. Vol. 8. P. 997-1000.

10. Chakrabarti D. J., Laughlin D. E., Shen S. W., Chang Y. A. Cu-Ni (Copper-Nickel) Binary Alloy Phase Diagrams // T. B. Massalski (Ed.), ASM International: Materials Park, OH, USA. 1990. Vol. 2. P. 1442-1446.

11. Selwood P. W. Magnetochemistry, $2^{\text {nd }}$ Ed. // Interscience. New York, USA, 1956.

12. Ackerbauer S., Krendelsberger N., Weitzner F., Hiebl K., Schuster J. C. The Constitution of the Ternary System Fe-Ni-Si // Intermetallics. 2009. Vol. 17. P. 414-420. 


\title{
КРИСТАЛІЧНА СТРУКТУРА ТА МАГНІТНІ ВЛАСТИВОСТІ
}

\author{
$\left(\mathrm{Cr}_{0,34} \mathrm{Cu}_{0,10} \mathrm{Ni}_{0,56}\right)_{4} \mathrm{Si}$
}

\author{
P.-І. Мартиняк ${ }^{1 *}$, Н. Муць ${ }^{1}$, А. Горинь ${ }^{1}$, Я. Токайчук ${ }^{1}$, М. Бобнар ${ }^{2}$, \\ Л. Аксельруд ${ }^{1,3}$, Р. Гладишевський ${ }^{1}$ \\ ${ }^{1}$ Кафедра неорганічної хімії, \\ Львівський наиіональний університет імені Івана Франка, \\ вул. Кирила і Мефодія, 6, 79005 Львів, Украӥна; \\ ${ }^{2}$ Кафедра фізики конденсованих систем, Інститут Йозефа Стефана, \\ вул. Ямова, 39, 1000 Любляна, Словенія; \\ ${ }^{3}$ Інститут хімічної фізики твердого тіла Товариства Макса Планка, \\ вул. Нотніщер, 40, 01187 Дрезден, Німеччина \\ e-mail: martyniak241@gmail.com
}

\begin{abstract}
Описано спробу одержання скирміонного матеріалу. Магнітні скирміони наноскопічні вихроподібні дефекти спінової текстури феромагнетиків, які завдяки своєму компактному розміру становлять науковий та індустріальний інтерес щодо їхнього застосування у пристроях збереження та відтворення інформації. Використання скирміонних матеріалів у пристроях цього типу може суттєво збільшити густину запису даних, що $є$ надзвичайно актуальним у XXI ст. Існування магнітних скирміонів у кристалах обмежується структурною та магнітною умовами, які полягають у тому, що структура скирміонного матеріалу повинна бути нецентросиметричною, а парамагнітна температура Кюрі - додатною.

Проведено повне уточнення кристалічної структури фаз полікристалічного зразка $\mathrm{Cr}_{26} \mathrm{Cu}_{9} \mathrm{Ni}_{47} \mathrm{Si}_{18}$ методом Рітвельда на основі дифракційних даних. 3'ясовано, що в цьому зразку кількісно переважає фаза складу $\left(\mathrm{Cr}_{0,34(1)} \mathrm{Cu}_{0,10(1)} \mathrm{Ni}_{0,56(1)}\right) 4 \mathrm{Si}$ (96.3(3) мас. \%). Кристалічна структура цієї фази належить до структурного типу $\mathrm{Au} 4 \mathrm{Al}$ (символ Пірсона $c P 20$, просторова група $\left.P 2{ }_{1} 3\right)$ : параметр елементарної комірки $a=0,612269(8)$ нм для $\left(\mathrm{Cr}_{0,34(1)} \mathrm{Cu}_{0,10(1)} \mathrm{Ni}_{0,56(1)}\right)_{4} \mathrm{Si}$ (склад визначено енергодисперсійною рентгенівською спектроскопією). Тип $\mathrm{Au} 4 \mathrm{Al}$ належить до родини структур, похідних до $\beta \mathrm{Mn}$.

Зразок $\mathrm{Cr}_{26} \mathrm{Cu}_{9} \mathrm{Ni}_{47} \mathrm{Si}_{18}$ досліджували методом високотемпературної диференціальної скануючої калориметрії. Аналіз отриманої кривої засвідчив відсутність будь-яких перетворень для фази $\left(\mathrm{Cr}_{0.34(1)} \mathrm{Cu}_{0.10(1)} \mathrm{Ni}_{0.56(1)}\right)_{4} \mathrm{Si}$ в температурному інтервалі 293-1123 K.

Для зразка $\mathrm{Cr}_{26} \mathrm{Cu}_{9} \mathrm{Ni}_{47} \mathrm{Si}_{18}$ досліджено температурну залежність магнітної сприйнятливості у магнітних полях індукцією 3,5 та 7,0 Тл. Уточнено, що для сполуки властивий КюріВайсовський парамагнітний характер магнітного впорядкування: $\chi_{0}=1,42 \cdot 10^{-4}$ e.м.о. г-ат ${ }^{-1} ; C=$ $2,7 \cdot 10^{-3}$ е.м.о. г-ат ${ }^{-1} \mathrm{~K}^{-1} ; \theta_{P}=-41 \mathrm{~K}$ у магнітному полі індукцією 3,5 Тл.
\end{abstract}

Ключові слова: рентгенівська порошкова дифракція, кристалічна структура, магнітні властивості, магнітні скирміони.

Стаття надійшла до редколегії 04.11.2019

Прийнята до друку 19.02.2020 